\title{
Novel Concept of an Installation for Sustainable Thermal Utilization of Sewage Sludge
}

\author{
Wilhelm Jan Tic ${ }^{1,2}$, Joanna Guziałowska-Tic ${ }^{1}$, Halina Pawlak-Kruczek ${ }^{3, *}$, \\ Eugeniusz Woźnikowski ${ }^{2}$, Adam Zadorożny ${ }^{2}$, Łukasz Niedźwiecki ${ }^{3}$ (i), \\ Mateusz Wnukowski ${ }^{3}$, Krystian Krochmalny ${ }^{3}$, Michał Czerep ${ }^{3}$, \\ Michał Ostrycharczyk ${ }^{3}$, Marcin Baranowski ${ }^{3}$, Jacek Zgóra ${ }^{3}$ and Mateusz Kowal $^{3}$ \\ 1 Department of Environmental Engineering, Opole University of Technology, 45-758 Opole, Poland; \\ w.tic@po.opole.pl (W.J.T.); j.guzialowska@po.opole.pl (G.-T.) \\ 2 West Technology \&Trading Polska Sp. z o.o., 45-641 Opole, Poland; ew@wttpolska.pl (E.W.); \\ az@wttpolska.pl (A.Z.) \\ 3 Department of Boilers, Burners and Energy Systems, Wroclaw University of Science and Technology, \\ 50-370 Wrocław, Poland; lukasz.niedzwiecki@pwr.edu.pl (Ł.N.); mateusz.wnukowski@pwr.edu.pl (M.W.); \\ krystian.krochmalny@pwr.edu.pl (K.K.); michal.czerep@pwr.edu.pl (M.C.); \\ michal.ostrycharczyk@pwr.edu.pl (M.O.); marcin.baranowski@pwr.wroc.pl (M.B.); \\ jacek.zgora@pwr.wroc.pl (J.Z.); mateusz.kowal@pwr.edu.pl (M.K.) \\ * Correspondence: halina.pawlak@pwr.edu.pl; Tel.: +48-71-320-3942
}

Received: 16 February 2018; Accepted: 22 March 2018; Published: 26 March 2018

\begin{abstract}
This study proposes an innovative installation concept for the sustainable utilization of sewage sludge. The aim of the study is to prove that existing devices and technologies allow construction of such an installation by integration of a dryer, torrefaction reactor and gasifier with engine, thus maximizing recovery of the waste heat by the installation. This study also presents the results of drying tests, performed at a commercial scale paddle dryer as well as detailed analysis of the torrefaction process of dried sewage sludge. Both tests aim to identify potential problems that could occur during the operation. The scarce literature studies published so far on the torrefaction of sewage sludge presents results from batch reactors, thus giving very limited data of the composition of the torgas. This study aims to cover that gap by presenting results from the torrefaction of sewage sludge in a continuously working, laboratory scale, isothermal rotary reactor. The study confirmed the feasibility of a self-sustaining installation of thermal utilization of sewage sludge using low quality heat. Performed study pointed out the most favorable way to use limited amounts of high temperature heat. Plasma gasification of the torrefied sewage sludge has been identified that requires further studies.
\end{abstract}

Keywords: sewage sludge; torrefaction; gasification; drying; sustainability

\section{Introduction}

\subsection{Introduction}

Sewage sludge is a waste that comes from the processing of wastewater. It is a biologically active mixture that consists predominantly of water and contains organic matter, dead or alive microorganisms, including pathogens, as well as toxic contaminants such as polycyclic aromatic hydrocarbons (PAHs) or heavy metals [1,2]. Currently management methods involving storage are being replaced in the EU by methods leading to waste stabilization and safe recycling [3]. Moreover, landfilling is deemed to be the most costly way to dispose of the sewage sludge, with average total costs ranging from 260 to $350 € / \mathrm{t}$ of dry matter [4]. 
Land spreading is an alternative utilization route that allows the use of nutrients still present in the sewage sludge. Land spreading is the most cost effective way to dispose of sewage sludge, from an overall economic point of view, with an estimated total cost between 110 and $160 € / t$ of dry matter [4]. Land spreading of composted sewage sludge as well as land spreading in sylviculture and land reclamation practices bear slightly higher overall cost, ranging from 210 up to $250 € / \mathrm{t}$ of dry matter [4]. Also in this case, properties and composition of the sewage sludge are of crucial importance, especially from the landowner's perspective, due to his potential liability [5].

Incineration and co-incineration are also feasible options. Besides influencing the technical aspects of a combustion installation, some of the fuel properties (moisture content and ash content) are detrimental from a point of view of the logistics, which prevents one from taking full advantage of the effect of scale in large power and combined heat and power (CHP) plants as in the cement industry, due to transportation costs. Total cost of disposal via incineration is deemed to be on average comparable with landfilling [4], although caution is advised since much depends on the overall supply chain.

Due to increasing amounts of environmental restrictions, not favorable to commonly used utilization pathways, such as landfilling [6], novel thermal processes are currently a subject of active investigation, in terms of their suitability for sewage sludge utilization as well as their applicability for other waste streams. It seems reasonable to pursue two distinctive paths in order to mitigate problems related with sewage sludge:

(A) Upgrade sewage sludge into a fuel with better fuel properties and increased energy density. Enabling the possibility of further removal of pathogens would be a significant gain from the health and safety perspective.

(B) Utilize sewage sludge using a thermal process that can potentially make inorganic residues easier to handle (turn it into a useful by-product or at least allow storage at a regular landfill).

\subsection{Novelty and Relevance Aspects of the Proposed Installation along with the Scope of Work}

Currently there is little literature data available on installations for thermal utilization of sewage sludge, capable of achieving full sustainability, i.e., the ability to sustain its work without any external source of heat and electricity. This paper presents the results of drying and torrefaction of sewage sludge and offers a holistic solution, based on the obtained results. The presented results allow one to draw meaningful conclusions in terms of the detailed choice of the individual elements of the system as well as suitable operational parameters for the proposed installation.

The main goal of the study is to prove existing devices and technologies allow the construction of an installation for sustainable utilization of sewage sludge, by integration of a dryer, torrefaction reactor and gasifier with engine, thus maximizing the recovery of the waste heat by the installation. The study aims to identify the most suitable unit operations, that should be included in the proposed installation. Justification of each of the proposed elements is based either on the performed tests or on the available literature data. Feasibility is assessed in conjunction with possible influence of the elements on the overall operation and maintenance of such unit. Due to scarce amount of literature studies published so far on the composition of the torgas from torrefaction of sewage sludge, results from the torrefaction of sewage sludge in a continuously working, laboratory scale, isothermal rotary reactor are presented. Moreover, torrefaction reactor of feasible scale is described in details, including brief description of the operational advantages of the proposed solution. Literature data on slagging gasifiers, used for gasification of low quality solid fuels, is discussed in the paper. Special emphasis is put on the plasma gasification as a potentially feasible technology from the operational point of view. 


\section{State of the Art-the Foundations of the Proposed Concept}

\subsection{Dewatering and Drying of Sewage Sludge}

Water distribution in the sewage sludge, determined by the factors such as structure and origin, is crucial in terms of its dewatering and drying propensity. According to the literature, moisture in the sewage sludge takes forms of [7]:

- Free water that is not bound, in any way, by the particles of the sludge

- Interstitial water, trapped by the flocs of solids or existing in capillaries

- Surface water, held by adhesion and adsorption

- Intracellular and chemically bound water

Another classification is process oriented and distinguishes between free water, that can be removed by mechanical dewatering and bound water, that is left after mechanical dewatering [7]. Free water from the latter classification includes free moisture from the former classification as well as a part of interstitial and surface moisture [7].

Among conventional dewatering technologies one can distinguish belt presses, which according to some sources are capable of achieving $15 \%$ up to $25 \%$ of dry matter, from the activated sludge with initial dry solid concentration of $2 \%$ up to $5 \%$ [7]. Other available, conventional, technologies are screw presses, rotary presses and centrifuges $[7,8]$. Peeters described an innovative machine that combines mechanical dewatering and drying in one compact unit [9]. This technology requires natural gas to generate hot sweeping gas (flue gas), that sweeps the volume of the dryer at temperatures between $230^{\circ} \mathrm{C}$ and $260{ }^{\circ} \mathrm{C}[9]$.

The review by Bennamoun et al. distinguishes three main drying methods: conductive drying, convective drying and solar drying [10]. Conductive dryers rely solely on indirect heating, whereas convective dryers rely on convection and to some extent on conduction (for example in the case of rotary dryers), while solar drying is based on solar radiation [10]. The aforementioned review also connects removal of a free moisture with constant drying rate, removal of interstitial water with the first falling rate (linear) and removal of surface water with the second falling rate (non-linear) [10]. During convective drying three phenomena can be observed: shrinkage, cracks and skin formation [10]. During conductive drying, torque variations undergo three phases: pasty, lumpy and granular [10], each of them exhibiting different rheological behavior [11]. Constant evaporation rate was observed by Arlabosse at al. pasty phase, whereas a linear decrease was observed during the granular period [12].

One of the problems with drying of the sewage sludge is related to its cohesive behavior, that becomes most intensive within certain levels of moisture content of the dried sewage sludge $[13,14]$. Changes in the rheological behavior are caused by the increased concentration of extra cellular polymers, mainly because of the increase of their respective concentrations, due to the loss of water [14]. These polymers originate both from microorganisms present in the sludge and flocculants added prior to dewatering $[14,15]$. Peeters et al. proposed using polyaluminium chloride as an additive to prevent the formation of the sticky phase [15].

Among convective dryers one can distinguish fluidized bed dryers, flash dryers, rotary dryers and belt dryers [10]. Among conductive dryers popular designs include disc dryer and thin film dryer [10] as well as paddle dryer [10,16].

Energy consumption per $\mathrm{kg}$ of removed water for convective dryers is reported to vary between 2520 and $5040 \mathrm{~kJ} / \mathrm{kg}_{\text {water, }}$ whereas for conductive dryers the consumption is lower, varying between 2880 and $3438 \mathrm{~kJ} / \mathrm{kg}_{\text {water }}$ [10].

\subsection{Dry and Wet Torrefaction and Pyrolysis of Sewage Sludge}

As much as drying is of the highest significance, some potential in the area is presented by both dry and wet torrefaction (also known as hydrothermal carbonization-HTC). Torrefaction is a thermal treatment performed under anaerobic conditions and elevated temperature (typically $250{ }^{\circ} \mathrm{C}$ 
to $300{ }^{\circ} \mathrm{C}$ ) [17]. Wet torrefaction is also performed under elevated temperature, in saturated water, and has been proven as a viable means to decrease the ash content of solid fuels [18,19].

Some amount of work on thermal treatment for utilization of the sewage sludge has been performed, including some fundamental work, using thermogravimetric analysis [20,21]. Huang et al. torrefied waste from pulp industries in a laboratory scale, batch reactor and determined energy densification ratios varying from 1.26 up to 1.5 depending on the process conditions [22]. Studies performed by Huang et al. on microwave co-torrefaction of sewage sludge with leucaena reported synergistic effect between the two feedstocks, during torrefaction [23,24]. An increase in higher heating value on dry, ash free basis, reaching $48 \mathrm{MJ} / \mathrm{kg}$ was reported [23]. Achieved ratios of $\mathrm{O} / \mathrm{C}$ and $\mathrm{H} / \mathrm{C}$ were similar to those of anthracite [23]. Huang et al. investigated kinetics of the torrefaction of the sewage sludge, using the simplified distributed activation energy model [25]. Lim et al. performed calculations of the performance of a hypothetical plant, that used fry-drying and torrefaction as unit operations along with a steam boiler using a part of the product [26]. Study concluded that the installation would be self-sufficient with an additional output of $33 \%$ of the dry solid mass originally fed to the dryer, converted to a solid biofuel [26].

Pulka et al. established that torrefaction increases the higher heating value (HHV) of the pretreated material on a dry ash free (daf) basis, although the change in HHV was not as significant due to the increased ash content of torrefied samples [27]. Increase in ash content and HHV was also observed by Poudel et al. [28]. Poudel et al. also observed increase in ash content of sewage sludge blends with waste wood [29]. Atienza-Martinez et al. successfully torrefied sewage sludge both in a fluidized bed reactor [30] and in an auger reactor [31]. In both cases a bit more reasonable residence times were investigated (13 to $35 \mathrm{~min}$ for auger reactor and $3.6 \mathrm{up}$ to $10.2 \mathrm{~min}$ for fluidized bed), in comparison to other authors ( $1 \mathrm{~h}$ ). Decrease in the energy density was observed in both cases (dry basis).

Wet torrefaction of sewage sludge has been investigated by $\mathrm{He}$ et al. [32] and Denso-Boateng et al. [33]. Both groups observed increase in ash content of hydrochars in comparison with raw sewage sludge, which is most likely a consequence of a much more profound loss of organics, in comparison to inorganics. Denso-Boateng et al. [34] also successfully performed wet torrefaction using primary sewage sludge. In this case an increase of the ash content could also be observed. HTC of the slaughterhouse cake, performed by Oh and Yoon demonstrated increase in the heating value of that residue and found optimum temperature of the HTC process to be $180{ }^{\circ} \mathrm{C}$ for that type of feedstock [35].

Pyrolysis of sludge has been a subject of a significant amount of studies [36-40]. Baltrenaite and Peckyte studied the properties of pyrolysis product of various types of industrial sewage sludge (from paper and leather industries) [41]. Performed research indicated, that the form of biochar restrained leaching of heavy metals [41], despite that concentrations were considerable, when compared with the restrictions set by the regulations [42]. Assessment of environmental effects performed by Wang et al. concluded that carbonization of the sewage sludge has overall positive environmental impact in comparison with landfilling and incineration [43]. However, special care should be taken in the cases when composition of a particular sludge makes leaching a problem during a subsequent utilization of the product of pyrolysis.

\subsection{Slagging Gasifier as a Feasible Tool for Gasification and Inertization of Solid Residues}

Slagging gasifiers could be a feasible solution, for the cases when inert solid residues are needed to solve the leaching problem. There are many different thermal conversion technologies that produce gas from solid fuel and the interest in these technologies as a viable mean of thermal utilization of sewage sludge has been recently reviewed $[44,45]$. As it has been already mentioned, solid residues from utilization of sewage sludge are a subject of strict regulations due to negative impact that might be caused by the leaching. In that context technologies that have a potential to limit the leaching are preferable. 
There is a wide variety of technologies designed for different types of waste materials that offer a feature of a vitrification of the predominantly inorganic residues. The Purox process, developed at the Linde division of Oxide Carbide, is an updraft, fixed bed, slagging gasifier that uses oxygen as a gasifying agent [46]. It was patented in 1973. An operating plant with designed capacity of $200 \mathrm{t} / \mathrm{d}$ was built in South Charleston and operated on municipal solid waste (MSW) between 1974 and 1978 (75 t/d was reached) [46]. Also twin $100 \mathrm{t} / \mathrm{d}$ units were built at Showa Denko (Chichibu, Japan) and operated between 1981 and 1997 [46]. The process consumed roughly $0.2 \mathrm{t}$ of $\mathrm{O}_{2}$ per $\mathrm{t}$ of waste, pressure swing absorption being used for production of oxygen [46].

Caliqua (the Heat and Power division of the French company Sofresid) developed a slagging fixed bed gasifier, working with preheated air in 1979 [46]. The throughput capacity of the gasifier was designed to be $8 \mathrm{t} / \mathrm{h}$ of MSW (LHV of MSW 7.92 MJ $/ \mathrm{kg}$ ) [46]. Gas was burned and heat was recovered in a Heat Recovery Steam Generator (HRSG), that allowed 1.5 MW electric output and 10.5 MW of heat output to the district heating network [46]. The calculated efficiency reached 68\% [46].

The Twin Rec process, developed by Japanese company Ebara, splits fluidized bed gasification and melting of the inorganics into two distinct stages. Vitrification of the fly ash is performed in the cyclonic ash melting furnace. Flue gases are used to generate steam [47]. Technology is fully commercial. Within a portfolio of the company projects installation sizes range from $15.7 \mathrm{t} / \mathrm{d}$ of MSW (Joetsu, Japan; commissioned in 2000) up to two installations with capacity of $275 \mathrm{t} / \mathrm{d}$ (Tokyo Rinki, Japan; commissioned in 2006) [47]. Plants in Joetsu and in Aomori $(2 \times 225 \mathrm{t} / \mathrm{d}$; commissioned in 2000) have operated using sewage sludge [47].

Plants are typically CHP facilities. The plant in Aomori, for example, has installed power of $17 \mathrm{MW}_{\mathrm{el}}$ and $40 \mathrm{MW}_{\mathrm{th}}$. One exception is the Kurobe plant, where gas is used for melting residues containing copper for the purpose of recovering that metal [47].

A significant part of the inorganic solids can be used as a by-product. For instance in the Kawaguchi plant $(3 \times 140 \mathrm{t} / \mathrm{d}$; commissioned in 2002) by-products from one ton of utilized MSW are as follows [47]: $10 \mathrm{~kg}$ of recyclable metals (ferrous and aluminum), $95 \mathrm{~kg}$ of vitrified ash (aggregate), $20 \mathrm{~kg}$ of inert materials, $25 \mathrm{~kg}$ of fly ash.

Some processes use pyrolysis as a primary treatment. An example of such technology is the Thermoselect High Temperature Reactor (HTR) process developed in Switzerland. Pyrolysis is followed by high temperature, oxygen gasification in a slagging fixed bed. The first commercial plant (95 tpd) operated between 1992 and 1999 in Fondoce (Italy). More installations followed, mostly in Japan, but also in Karlsruhe, Germany [47].

Due to a high energy density and a possibility to obtain very high temperatures (couple thousand ${ }^{\circ} \mathrm{C}$ ) plasma technologies are considered to be a viable option for utilization of various waste types [48]. High temperature is generated by a plasma torch, which requires electricity to operate.

There are existing plasma gasification technologies that have been successfully implemented in the field of thermal conversion of MSW. The most mature, fully commercialized, is a process developed by Westinghouse Plasma Corporation and currently owned by Canadian company Alter NRG. Plasma Gasification Vitrification Reactor (PGVR) uses heat generated by plasma torches to gasify the waste and vitrify solid residues. Fully commercial facility was built in Utashinai, Japan by the EcoValley consortium. Installation was commissioned in April 2003 and ceased operation in 2013 [47], due to problems with obtaining sufficient quantities of feedstock [47]. Installation was designed to process MSW and Automobile Shredding Residues (ASR) in 50/50 proportion, with nominal processing capacity of $165 \mathrm{t} / \mathrm{d}$ [49]. Plant was able to achieve $220 \mathrm{t} / \mathrm{d}$ working with $100 \%$ of MSW [49]. Installation was able to meet strict Japanese emission criteria and vitrified slag shown limited solubility, which made it suitable to be used as an aggregate [47].

Syngas from the PGVR was burned in the refractory-lined combustor after-burner. Heat obtained this way was recovered in HRSG to generate steam for a steam turbine. Some operational problems have been reported [22,24]: cold spots in the coke bed, due to inadequate penetration by plasma torches [49]; too short life span of the refractory of the reactor-caused by adding additional refractory 
to remediate the problem of the cold spots [49]; erosion of the refractory of the after-burner (which caused the operator to lower the exit temperature of syngas from $1200{ }^{\circ} \mathrm{C}$ to $750{ }^{\circ} \mathrm{C}$ ) [49]. Reactor requires auxiliary substances to operate. For every ton of waste it requires (our own calculations based on data from [49]) $40 \mathrm{~kg}$ of coke and $74 \mathrm{~kg}$ of limestone.

\subsection{Plasma Gasification of the Sewage Sludge}

Considering sewage sludge plasma treatment there is a very limited information on the industrial installations and scarce amount of scientific papers on the topic. Montouris et al. determined, using the GasifEq equilibrium model, that plasma gasification of sewage sludge from Psittalia Island, can lead to a net production of electricity [50]. Assuming processing of $250 \mathrm{t} / \mathrm{d}$ of sewage sludge with moisture content of $68 \%$, modelled installation has shown possibility to supply electric power of 2.85 MW [50]. Tar conversion is crucial in the context of gasification since their presence can cause technical problems-its removal is important if the gas is planned to be used in turbines, engines or subsequent synthesis [51]. Two research groups conducted successful experiments with a two-step plasma processing units [52,53]. In both cases applying plasma improved the gas quality. During the study performed by Striugas et al. the use of arc plasma allowed to achieve over 99\% conversion of tar, while the raw syngas composition was not a subject of a significant change [53]. In the second work, a microwave plasma reactor was used to reform a raw syngas, derived from the sewage sludge gasification. In the research, it was shown that applying plasma resulted not only in the tar content decrease (with conversion form $70 \%$ to $100 \%$ depending on the analyzed compound) but also in a significant improvement in the gas composition [52].

Plasma gasification is more flexible in terms of the quality of the fuel, in comparison with typical slagging gasifiers, as it uses electricity to deliver a heat in the form of hot plasma. However, in terms of the sewage sludge, it is desired to remove as much moisture as possible, before feeding the sludge into the gasifier, in order to improve the heat balance of the installation.

\subsection{State of the Art-Summary}

Drying of the sewage sludge is a relatively well known process, with a significant amount of published investigations. Drying of the sewage sludge is a mature technology and knowledge on the operational issues, such as increased stickiness of the sludge during drying, is extensive. Special emphasis should be put on the suitability of the dryer for the specific parameters of a sewage sludge and a waste heat source.

There are some works available on the torrefaction of sewage sludge. However, little is known on the composition of torgas, which is often an operational issue for the torrefaction installation. Technology selected for the proposed installation should have a design features capable of minimizing operational problems related with condensation of tars.

Possibility to obtain inert solid by-product, not susceptible to leaching, is the main advantage of the plasma gasification. Moreover, high temperatures of the process are potentially good for utilization of torgas, without the need to build a separate burner.

\section{Materials and Methods}

Samples of feedstock were obtained at the sewage treatment plant in Brzeg Dolny. Samples of the sewage sludge were obtained after fermentation and mechanical dewatering stages of the sewage treatment. Detailed characterization of the raw material is presented in Table 1, below.

Standard proximate analysis and ultimate analysis of both raw sewage sludge and torrefied product, was performed according to European Standards. References of all the relevant standard procedures are presented in Tables 1 and 4 (required accuracies are stated in the respective standards). 
Table 1. Proximate and ultimate analysis of the sample of sewage sludge from Brzeg Dolny water treatment plant (after mechanical dewatering).

\begin{tabular}{ccccc}
\hline Test & Symbol & Value & Unit & Standard Procedure \\
\hline Moisture content ${ }^{1}$ & $\mathrm{MC}$ & 83.90 & $\%$ & EN ISO 18134-2:2015 \\
Volatile matter content $_{\text {Ash content }}$ & $\mathrm{VM}^{\mathrm{d}}$ & 62.40 & $\%$ & EN 15148:2009 \\
Higher heating value & $\mathrm{A}^{\mathrm{d}}$ & 33.40 & $\%$ & EN ISO 1822:2015 \\
Lower heating value $^{2}$ & $\mathrm{HHV}$ & 16,100 & $\mathrm{~kJ} / \mathrm{kg}$ & EN 14918:2009 \\
Carbon content & $\mathrm{LHV}$ & 661.1 & $\mathrm{~kJ} / \mathrm{kg}$ & EN 14918:2009 \\
Hydrogen content & $\mathrm{C}^{\mathrm{d}}$ & 38.05 & $\%$ & EN ISO 16948:2015 \\
Nitrogen content & $\mathrm{H}^{\mathrm{d}}$ & 3.85 & $\%$ & EN ISO 16948:2015 \\
Sulfur content & $\mathrm{N}^{\mathrm{d}}$ & 5.55 & $\%$ & EN ISO 16948:2015 \\
Oxygen content & $\mathrm{S}^{\mathrm{d}}$ & 0.95 & $\%$ & EN ISO 16994:2016 \\
\hline
\end{tabular}

${ }^{1}$ Wet basis; ${ }^{2}$ Calculated using the formula from the standard; ${ }^{\mathrm{d}}$ Dry basis.

Diagram of the installation with a paddle dryer, used for drying trials, is presented at Figure 1. Drier was operated in a batch mode. A suite of three consecutive drying tests was performed using the same batch of material for each test. Initial batch size was approximately $1 \mathrm{t}$. Sludge was recirculated after each test (see Table 2) in order to obtain a product with moisture content below $5 \%$. Dryer used for the tests was $2.5 \mathrm{~m}$ long, $1 \mathrm{~m}$ wide and $1 \mathrm{~m}$ high (outside dimensions), with heat exchanging surfaces of approximately $10 \mathrm{~m}^{2}$.

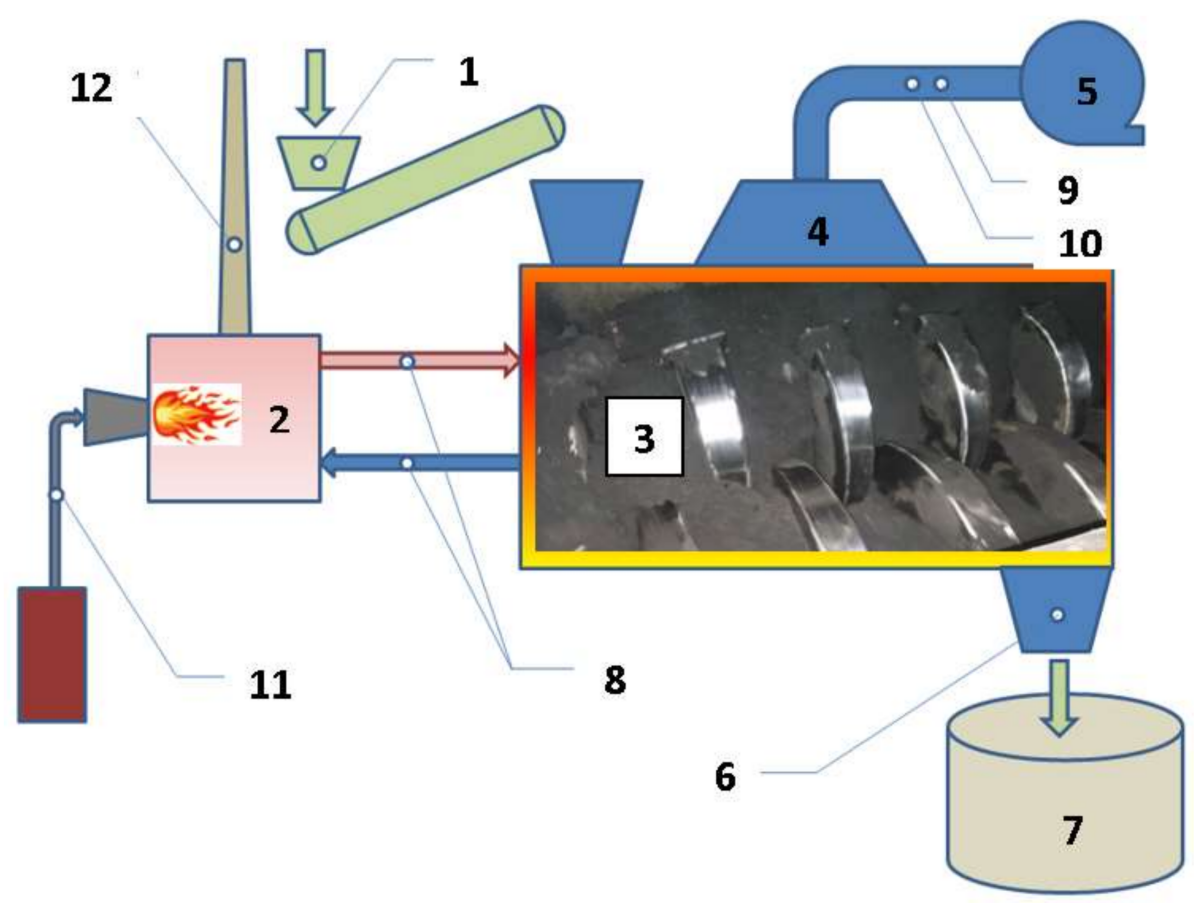

Figure 1. Diagram of the paddle dryer used for drying tests (1-feeding line of wet sewage sludge; 2-thermal oil boiler with oil burner; 3-paddle dryer; 4-outlet of the mixture of air and vapors; 5-extraction fan; 6-outlet of dried sewage sludge; 7-tank with dried sewage sludge; 8-temperature measurement for hot thermal oil supply and return; 9-sampling of the vapors with measurement of the velocity and temperature; 10-measurement of the relative humidity; 11—supply of the fuel oil to the burner; 12 -stack). 
Table 2. Results of the drying tests, performed with commercial scale paddle dryer.

\begin{tabular}{cccccc}
\hline Test & Symbol & Test 1 & Test 2 & Test 3 & Unit \\
\hline Moisture content of the feedstock ${ }^{1}$ & $\mathrm{MC}_{\text {in }}$ & 83.90 & 53.47 & 32.13 & $\%$ \\
Moisture content of the dried sewage sludge ${ }^{1}$ & $\mathrm{MC}_{\text {out }}$ & 53.47 & 32.13 & 4.02 & $\%$ \\
\hline Residence time & $\mathrm{t}_{\text {res }}$ & 75 & 55 & 60 & $\mathrm{~min}$ \\
Average temperature of the thermal oil $^{2}$ & $\mathrm{~T}_{\text {oil }}$ & 178.7 & 177.2 & 183.3 & ${ }^{\circ} \mathrm{C}$ \\
Relative humidity of the air at the outlet of the dryer & $\mathrm{RH}$ & 60 & 62 & 58 & $\%$ \\
Mass of dried sludge & $\mathrm{m}_{\text {wet }}$ & 966 & 329 & 227 & $\mathrm{~kg}$ \\
Mass of removed water & $\mathrm{m}_{\text {vap }}$ & 637 & 102 & 66 & $\mathrm{~kg}$ \\
\hline
\end{tabular}

${ }^{1}$ Wet basis; ${ }^{2}$ Inside of the dryer.

Due to the size of the dryer and the sample itself, mass and energy balances of the dryer were both performed, using the indirect method. Volumetric flow rate of the mixture of vapors and air, out of the dryer, was measured, by measurement of the velocity of the gases in the duct. Sampling probe, used in the tests, had an integrated pitot probe, thus allowing measurement of the velocity of the gases in the duct. Due to relatively low diameter of the ducting $(200 \mathrm{~mm})$ and relatively high velocities in the ducting (between 10 and $20 \mathrm{~m} / \mathrm{s}$ ) velocity was measured in a single point of the cross section of the circular duct, and the velocity distribution was assumed to resemble the one of a plug flow. Uncertainty of the velocity measurement was $\pm 2 \%$ of the measured velocity. Single sampling point is typical for the determination of low range mass concentration of dusts, for ducts with diameter smaller and equal to $350 \mathrm{~mm}$ [54]. Measurement of the relative humidity allowed to determine concentration of water vapors carried by air, using a Mollier diagram. Measurement was performed using a Testo 435 analyzer, with an accuracy of $\pm 2 \%$ of the measuring range (0 to $100 \%$ Relative Humidity-RH). Energy balance was determined based on the flow rate of the thermal oil and the temperature difference between flow and return of the thermal oil. Flow rate of the thermal oil was performed using an ultrasonic flow meter FSD32 (Fuji Electric) with measuring range of 0.3 to $32 \mathrm{~m} / \mathrm{s}$, for temperatures of the fluid ranging from $-40{ }^{\circ} \mathrm{C}$ up to $20{ }^{\circ} \mathrm{C}$ and accuracy of $\pm 0.02 \mathrm{~m} / \mathrm{s}$. Flow meter was installed respectively more than 10 nominal diameters downstream and more than 5 nominal diameters upstream from the nearest obstacle. Distance from the nearest pump was higher than 50 nominal diameters. Temperature was measured using 1 st class, $\mathrm{K}$ type thermocouples, with measurement uncertainty of $1.5^{\circ} \mathrm{C}$.

Torrefaction tests were carried out at a laboratory scale using isothermal rotary reactor presented at Figure 2. The core part of this test rig was a rotating pipe made of heat resistant steel and externally heated by a set of electric heaters. Test rig had its own temperature control system that could maintain temperature, set by the operator, up to maximum of $1000^{\circ} \mathrm{C}$. Temperature was measured at the outside surface of the pipe by three thermocouples, one in the middle and two on both ends of the heated pipe. Samples of the torgas were taken by the sampling probe introduced to the inside of the rotating pipe (at the far end of the pipe, along the central axis; No. 9 in Figure 2). All the solid products were collected at the bottom of the drop, out of the far end of the pipe (No. 8 in Figure 2).

Condensable gaseous compounds, present in torgas, were captured by the set of impinger bottles connected in series. Bottles were filled with isopropanol and cooled with thermostatic bath, keeping the temperature at $-10^{\circ} \mathrm{C}$. Cold gas went through a conditioning unit in order to get rid of any residual moisture and filter all the remaining particulate impurities. Gaseous (non-condensable) products of torrefaction were measured using a Gasmet CX 4000 FTIR analyzer (Gasmet Technologies Oy, Company, Helsinki, Finland). Calibration of the analyzer was performed using nitrogen of 5.0 quality prior to measurements. The analyzer has a zero drift and linearity drift smaller than $2 \%$ of the range for each of the respective compounds.

Samples of the solutions from both impinger bottles were subsequently analyzed using GC-MS, which consisted of an Agilent 7820-A chromatograph (Agilent Technologies, Palo Alto, CA, USA) and an Agilent 5977B MSD spectrometer (Agilent Technologies, Palo Alto, CA, USA). In the chromatograph 
a Stabilwax-DA column (Restek) (Restek, Benner Circle, Bellefonte, PA, USA) was used. Helium was used as a carrier gas $(1.5 \mathrm{~mL} / \mathrm{min})$. Heating up program was set to achieve $50{ }^{\circ} \mathrm{C}$ in $5 \mathrm{~min}$ and subsequently heat up the column with a ramp of $10^{\circ} \mathrm{C} / \mathrm{min}$ until the temperature of $200{ }^{\circ} \mathrm{C}$ was reached and hold for another $20 \mathrm{~min}$. The data obtained with GC/MS was analyzed using the base peak chromatograms (BPC). Each sample was analyzed three times and the obtained results present an average value.

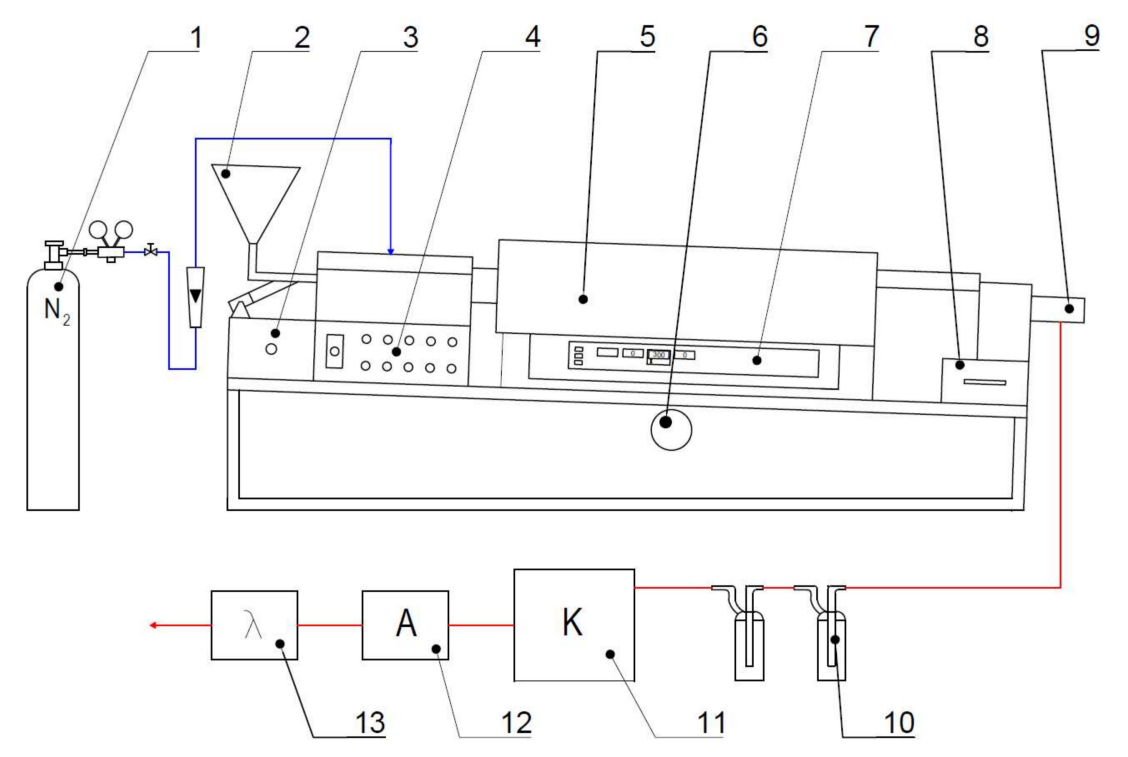

Figure 2. Diagram of the rotary isothermal torrefaction reactor $(1-$ cylinder with nitrogen; 2 -feedstock hopper; 3-electric motor; 4-control panel; 5-rotary drum; 6-regulation of the tilt; 7-temperature control panel; 8-container with torrefied product; 9-sampling of torgas; 10-impinger bottles; 11 -conditioner; 12 -FTIR gas analyzer; 13 -Electrochemical $\mathrm{O}_{2}$ analyzer).

\section{Results}

Results of the drying tests performed with the commercial scale paddle dryer are shown in the Tables 2 and 3 below. Tests from 1 to 3 were performed in a series, i.e., the material dried during test number 1 was subsequently recirculated back to the dryer and became the feedstock for test number 2 , etc. This way cause it was possible to overcome limitations, such as length of the dryer.

The amount of energy needed to drive off $1 \mathrm{~kg}$ of water, for each of three performed tests is presented in Table 3, below. Consumption of the heat and consumption of the electricity were calculated separately, using methods described in paragraph 2.

Results of the proximate and ultimate analysis of the sewage sludge, torrefied at $300{ }^{\circ} \mathrm{C}$ are presented in Table 4, below. Initial moisture content of feedstock, prior to torrefaction was $10.5 \%$.

Table 3. Energy consumed by the paddle dryer for the drying process for each of the tests.

\begin{tabular}{cccccc}
\hline Result & Symbol & Test 1 & Test 2 & Test 3 & Unit \\
\hline Average consumption of the heat & $\mathrm{E}_{\text {th }}$ & 4141 & 6300 & 7203 & $\mathrm{~kJ} / \mathrm{kg}_{\mathrm{H}_{2} \mathrm{O}}$ \\
Average consumption of the electricity & $\mathrm{E}_{\mathrm{el}}$ & 301 & 643 & 413 & $\mathrm{~kJ} / \mathrm{kg}_{\mathrm{H}_{2} \mathrm{O}}$ \\
Average total energy consumption & $\mathrm{E}_{\text {tot }}$ & 4441 & 6976 & 7615 & $\mathrm{~kJ} / \mathrm{kg}_{\mathrm{H}_{2} \mathrm{O}}$ \\
\hline
\end{tabular}


Table 4. Proximate and ultimate analysis of the torrefied sewage sludge.

\begin{tabular}{|c|c|c|c|c|}
\hline Test & Symbol & Value & Unit & Standard Procedure \\
\hline Moisture content ${ }^{1}$ & $\mathrm{MC}$ & 1.00 & $\%$ & EN ISO 18134-2:2015 \\
\hline Volatile matter content & $\mathrm{VM}^{\mathrm{d}}$ & 41.50 & $\%$ & EN 15148:2009 \\
\hline Ash content & $A^{d}$ & 48.00 & $\%$ & EN ISO 1822:2015 \\
\hline Higher heating value & HHV & 15,700 & $\mathrm{~kJ} / \mathrm{kg}$ & EN 14918:2009 \\
\hline Lower heating value ${ }^{2}$ & LHV & 15,515 & $\mathrm{~kJ} / \mathrm{kg}$ & EN 14918:2009 \\
\hline Carbon content & $C^{d}$ & 34.58 & $\%$ & EN ISO 16948:2015 \\
\hline Hydrogen content & $\mathrm{H}^{\mathrm{d}}$ & 2.73 & $\%$ & EN ISO 16948:2015 \\
\hline Nitrogen content & $\mathrm{N}^{\mathrm{d}}$ & 5.09 & $\%$ & EN ISO 16948:2015 \\
\hline Sulfur content & $S^{d}$ & 0.76 & $\%$ & EN ISO 16994:2016 \\
\hline Oxygen content & $\mathrm{O}^{\mathrm{d}}$ & 8.83 & $\%$ & EN ISO 16993:2015 \\
\hline
\end{tabular}

${ }^{1}$ Wet basis; ${ }^{2}$ Calculated using the formula from the standard; ${ }^{\mathrm{d}}$ Dry basis.

Major constituents of torgas are presented in Table 5 below. Except $\mathrm{N}_{2}$ which was an inerting agent for the reactor, torgas consisted mainly of water, carbon dioxide and condensable hydrocarbons (tars). Compounds, that are considered condensable in this paper, are the compounds that have their boiling point high enough to condense in the ambient conditions.

Table 5. Composition of torgas-major constituents.

\begin{tabular}{cccc}
\hline Result & Symbol & Value & Unit \\
\hline $\begin{array}{c}\text { Concentration of } \mathrm{CO}_{2} \text { in torgas } \\
\begin{array}{c}\text { Concentration of condensable } \\
\text { compounds in torgas }\end{array}\end{array}$ & $\mathrm{U}_{\mathrm{CO}_{2}}$ & 2.11 & $\%_{\mathrm{vol}}$ \\
\hline
\end{tabular}

Minor constituents, measured using the FTIR analyzer included simple, non-condensing (gaseous) hydrocarbons. The results of the measurements are shown at Figure 3. Their concentrations in torgas were insignificant, in comparison to the main components. However, this was caused partially by the dilution of the torgas by an inerting agent. Therefore constituents of torgas with concentrations sufficiently high (twice the detectability limit) are reported.

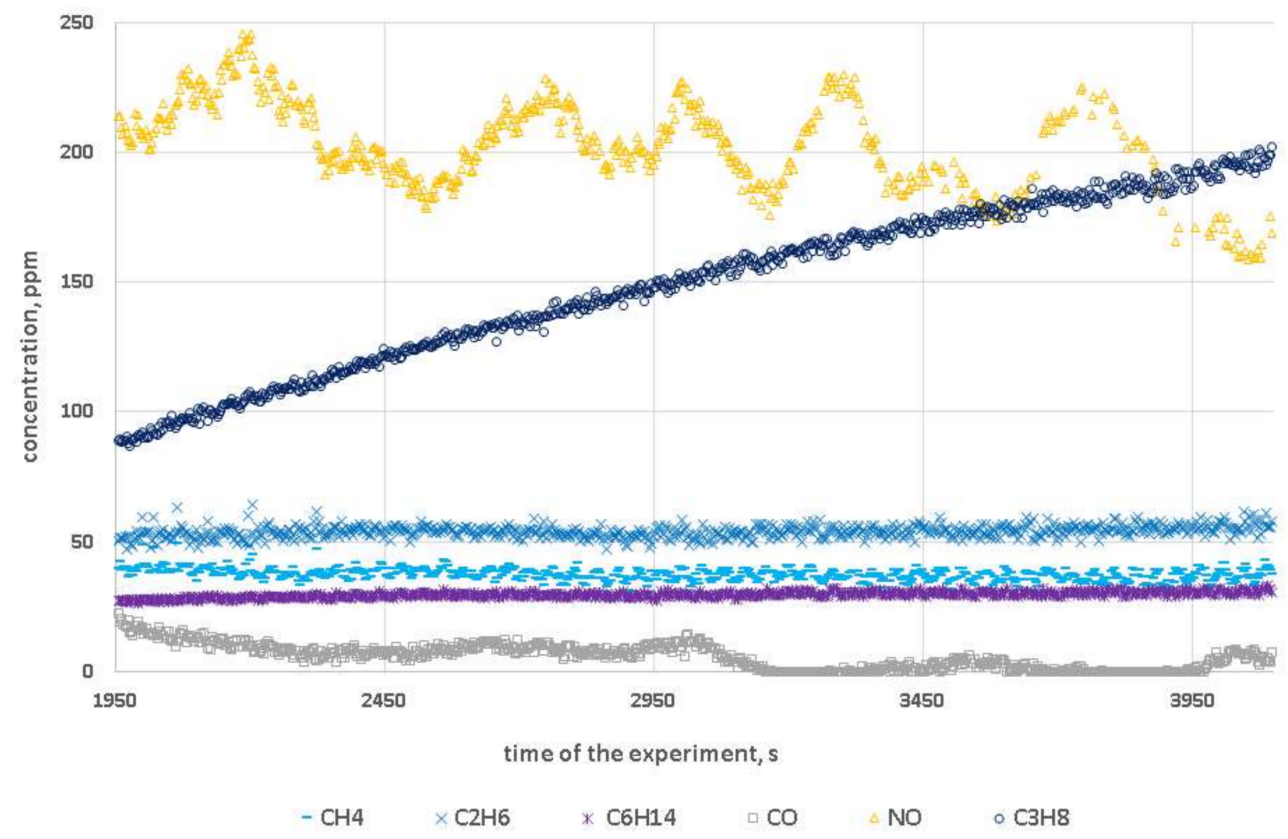

Figure 3. Composition of the torgas-minor constituents. 
Condensable compounds detected in the samples of solvent (isopropanol) solution, are reported in Table 6. All of these compounds are heterorganic, i.e., they contain atoms of S, $\mathrm{N}$ or $\mathrm{O}$ within their particles. Water, which was also present (in abundance) in the solutions from impinger bottles was not included in the respective tables. Results presented in Table 6 are qualitative.

Table 6. Compounds identified in the first impinger bottle, using GC-MS analysis.

\begin{tabular}{|c|c|c|c|c|}
\hline Compound & Boiling Point & Molecular Mass & Area of the Peak & Relative Area of the Peak ${ }^{2}$ \\
\hline & ${ }^{\circ} \mathrm{C}$ & $\mathrm{g} / \mathrm{mol}$ & a.u. $\left(10^{-6}\right)^{1}$ & $\%$ \\
\hline Trimethylamine & 2.9 & 59.11 & 1.73 & $76.4 \%$ \\
\hline Furan & 31.3 & 68.07 & 0.07 & $3.2 \%$ \\
\hline Acetone & 56 & 58.08 & 1.14 & $50.5 \%$ \\
\hline 2-Methylfuran & 63 & 82.1 & 0.47 & $20.6 \%$ \\
\hline Methyl Alcohol & 64.7 & 32.04 & 2.19 & $100.0 \%$ \\
\hline Acetonitrile & 82 & 41.05 & 0.54 & $23.7 \%$ \\
\hline Dimethyl disulfide & 110 & 94.19 & 1.19 & $52.6 \%$ \\
\hline$p$-Xylene & 138.4 & 106.16 & 0.20 & $9.0 \%$ \\
\hline Pyridine & 115.6 & 79.1 & 0.57 & $25.2 \%$ \\
\hline Pyrazine & 115 & 80.09 & 0.05 & $2.4 \%$ \\
\hline Isocapronitrile & 155 & 97.16 & 0.01 & $0.6 \%$ \\
\hline 2-Methylpyrazine & 135 & 94.11 & 0.25 & $11.2 \%$ \\
\hline 4-Aminopyridine & 273 & 94.11 & 0.11 & $4.7 \%$ \\
\hline Dimethyl trisulfide & 170 & 126.26 & 0.40 & $17.6 \%$ \\
\hline Acetic acid & 118.1 & 60.05 & 1.66 & $73.3 \%$ \\
\hline 1-(2-Furyl)ethanone & 173 & 110.11 & 0.05 & $2.3 \%$ \\
\hline Pyrrole & 129 & 67.09 & 0.74 & $32.9 \%$ \\
\hline 2-Methyl-1H-pyrrole & 148 & 81.12 & 0.07 & $3.0 \%$ \\
\hline Acetamide & 221.2 & 59.07 & 1.29 & $57.1 \%$ \\
\hline (E)-2-Butenoic acid & 185 & 86.09 & 0.08 & $3.4 \%$ \\
\hline Phenol & 181.7 & 94.11 & 0.13 & $5.6 \%$ \\
\hline Octanoic acid & 237 & 144.21 & 0.01 & $0.4 \%$ \\
\hline$p$-Cresol & 201.8 & 108.13 & 0.03 & $1.2 \%$ \\
\hline 3,4,5-Trimethylpyrazole & 170 & 110.16 & 0.11 & $4.9 \%$ \\
\hline 3-Pyridinol & 180 & 95.1 & 0.60 & $26.5 \%$ \\
\hline Indole & 254 & 117.15 & 0.35 & $15.4 \%$ \\
\hline Succinimide & 288 & 99.09 & 0.04 & $1.7 \%$ \\
\hline Dodecanoic acid & 298.9 & 200.32 & 0.06 & $2.8 \%$ \\
\hline$N$-(Pyridin-3-yl)acetamide & 327 & 136.15 & 0.26 & $11.3 \%$ \\
\hline$n$-Hexadecanoic acid & 351.5 & 256.43 & 0.05 & $2.3 \%$ \\
\hline
\end{tabular}

${ }^{1}$ Arbitrary units; ${ }^{2}$ Relative to the highest peak (Methyl Alcohol).

\section{Discussion}

\subsection{Discussion of the Obtained Results}

Sewage sludge is a non-Newtonian fluid, that poses some difficulties in a subsequent processing. Increase in the viscosity of the sludge, after partial drying can be clearly observed as an increased consumption of electricity by the installation. As parameters of the blowers and other auxiliaries had not been a subject of any significant change, this could be the only possible explanation of doubled consumption of electricity per kg of removed water during the second test. This is consistent with reports from various literature sources that state a profound change in the rheological properties of the sewage sludge after achieving certain level of moisture content [13-15,55]. In terms of the heat consumption for drying, specific drying heat was a subject of significant increase, with decreasing final moisture content of the dried material, which is by no means surprising. This could highlight potential problems with heat requirements, if deep drying was needed, which could significantly hamper the ambitions to obtain a self-sustaining installation. Latent heat of water could become a potential heat source. However, this would imply using another drying technology as high temperature heat sources are preferable for indirect-conductive units (paddle dryer), due to the constraints of heat transfer between hot surfaces and pasty dried material. Relative humidity of the gases at the outlet of the dryer was close to $60 \%$ in all of the cases, which gives some extra room for the optimization of the energy consumption by the dryer. Use of hybrid methods (convective-conductive) of drying might 
subsequently lead to significant decrease of energy/heat consumption, by enabling the possibility to recover heat from the vapors at the outlet of the dryer.

Torrefaction of the dried sewage sludge yielded the expected results, i.e., slight carbonization of the torrefied sludge and a significant decrease in the moisture content. The most profound change was the increase in ash content, as shown by the comparison of the results from Table 4 with the characteristics of the raw material, presented in the Table 1. This might not be a disadvantage in terms of a planned slagging gasifier and will be discussed further in more details. Moreover, relatively significant concentration of $\mathrm{NO}$ in the torgas is worth mentioning, as it clearly indicates the potential of the removal of nitrogen from the fuel by this technology.

Obtained torgas consisted mainly of condensable compounds and $\mathrm{CO}_{2}$, as shown in Table 5. Other gaseous constituents were present, as shown at Figure 3. However, their respective concentrations were insignificant, which could be partly contributed to the dilution caused by using inerting agent during the experiment $\left(\mathrm{N}_{2}\right)$. Interesting was the fact that among permanent gases concentrations of methane, ethane and hexane, were much higher than the concentration of carbon monoxide, which is different in comparison to other types of biomass, with higher initial content of volatile matter (such as for example wood, palm kernel shells, olive mill residues).

Results of the GC-MS analysis of the solutions from the impinger bottles confirmed the presence of significant amounts of different heterorganic compounds in the torgas from torrefaction of sewage sludge. Their respective concentrations are presented in Table 6. Area of the peak for each substance, can be used as a simplified indicator of their respective concentrations. However, it should be noted that it depends not only on the concentration of the compound but also on its structure, as well as on the temperature of the compound that leaves the column of the gas chromatograph. Moreover, some of the compounds could not be detected either due to their concentrations being below the limit of detectability or due to their equivocal mass distribution, that did not allow proper identification by the mass spectrometer. Nevertheless, the most dominant compounds are clearly trimethylamine, acetone, methyl alcohol, dimethyl disulfide, acetic acid and acetamide.

The presence of compounds with high boiling point, such as $n$-hexadecanoic acid or $\mathrm{N}$-(pyridin-3-yl) acetamide is particularly interesting, as in the case of this compound, the boiling point is higher than the temperature of the torrefaction. This might suggest the presence of such compounds on the surface of the torrefied material, which should be investigated further.

\subsection{A Concept of the Sustainable Installation for Utilization of Sewage Sludge}

The research group of Boilers, Combustion and Thermal Processes at Wroclaw University of Science and Technology, has developed and patented a flexible, multi stage tape reactor (Figure 4). This device depending on temperature regime can easily perform duties of dryer and/or torrefaction reactor. Successful trials of lignite drying and torrefaction of various types of biomass, have been performed in recent years [56,57].

Material fed into the reactor is being heated externally, through the surface of a metal plate. Material is being moved through the reactor by a chain conveying system and falls down from one plate into another, until it leaves the reactor.

Feedstock is being fed from the hopper, to the reactor also by a chain conveyor. On both ends of the reactor airlocks are being used to prevent the escape of torgas. Product is being cooled down in a screw conveyor with water jacket, at the bottom of the installation. Torgas is being burned in the combustion chamber, located beside the torrefier. An oil burner is used as a source of startup heat and as a pilot flame source during normal operation. When working in torrefaction mode installation is operating reasonably close to autothermal point, whereas the supply of auxiliary heat is determined by the moisture content of the feedstock. When working in drying mode, burner is the main source of heat.

The main advantage of such a solution is the fact that processed material is touching only hot surfaces of the reactor, thus significantly reducing the risk of the agglomeration of the particles, due to 
sticky tars condensing on the surfaces. This has a potential to reduce the operational cost, by reducing the risk of emergency shutdowns due to clogging.

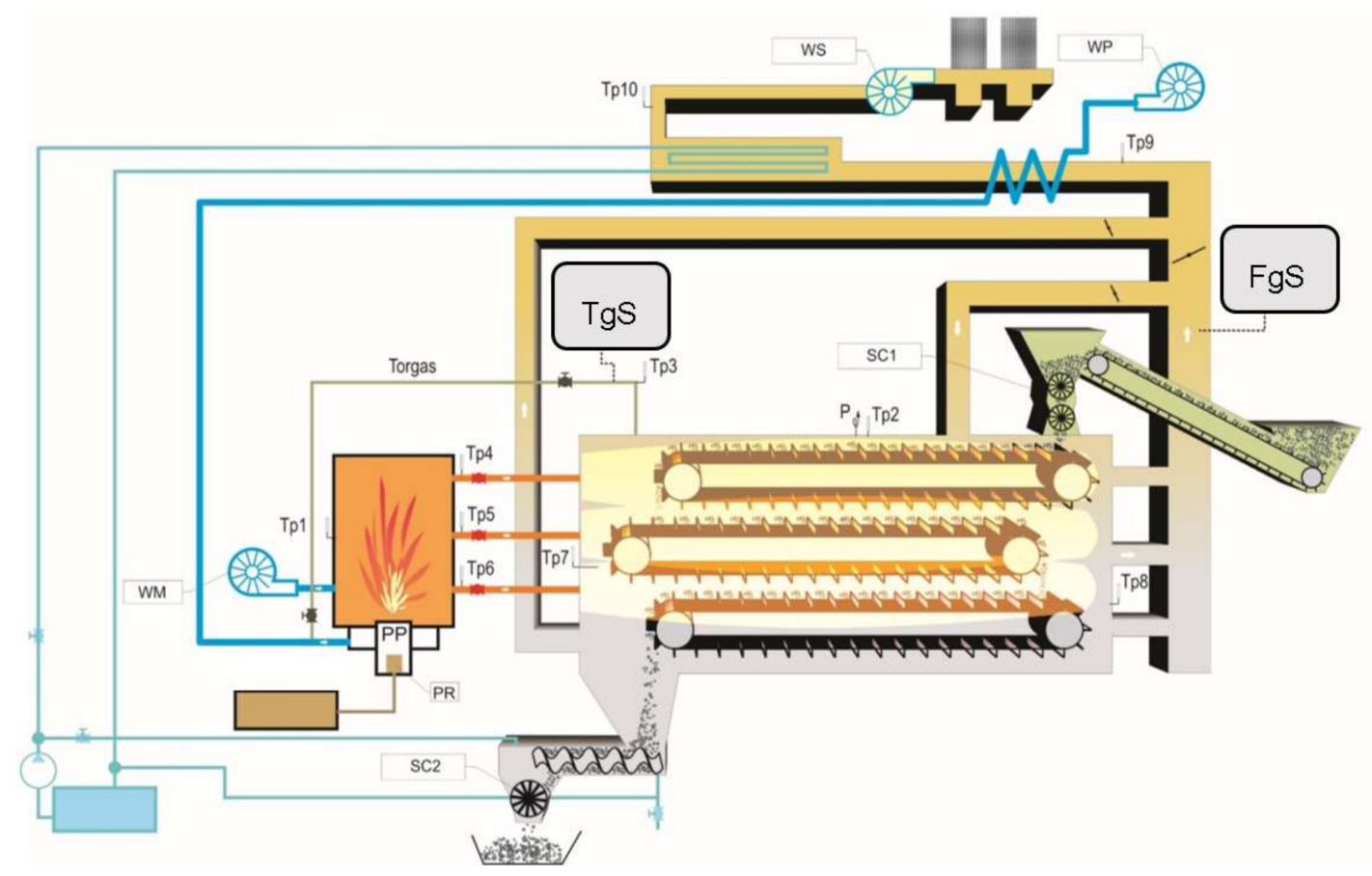

Figure 4. Multistage tape dryer/torrefier developed by Wroclaw University of Science and Technology (Tp-thermocouple; TgS-Torgas sampling port; FgS—Flue gas sampling port; WP_Preheated secondary air blower; WM-Primary air blower; WS—Flue gas extraction fan; SC1—airlock at the inlet; SC2—airlock at the outlet; $\mathrm{PR}$ - pressure regulator; $\mathrm{PP}$-oil burner; $\mathrm{P}$-pressure gauge).

Proposed installation for utilization of sewage sludge will use plasma gasification technology to produce syngas and vitrify inorganic by-products, as shown at the diagram, presented at Figure 5 . Syngas shall be used by the engine + generator set to generate electricity. Heat from the exhaust gases will be recovered, and used for torrefaction and drying. Taking into consideration the available amount of the latent heat of vaporization it seems problematic to rely solely on the paddle dryer, despite its obvious merits. Among those one can count a relatively small consumption of electricity, in comparison with dryers using high flow rates of air, that consequently require higher amounts of electricity for the blowers. Relatively small footprint and consequently a supposedly smaller investment cost can also be considered an advantage of such a unit. However, the amount of low temperature heat, available for the process under the assumption of implementation of condensing heat exchanger, might suggest either using staged drying consisting of two units connected in series, or using a much bigger indirect dryer, using air as a drying agent.

It seems tempting to eliminate torrefaction as a unit operation in the proposed installation. However, the energy consumption of the subsequent unit operation (plasma gasification) should be taken into the account. Not using torrefaction, would cause that the heat for heating up the material from the temperature at the exit of the dryer to $300^{\circ} \mathrm{C}$, would effectively come from conversion of electricity into heat in plasma torch. Moreover, carbonization of the sewage sludge during torrefaction could have a positive influence on the overall quality of the syngas produced in the gasifier, through higher amounts of carbon available for Boudouard reaction. This could be highly significant in a plasma gasification, where temperatures are substantially higher in comparison with other gasification technologies, which would make reactions such as Boudouard generally faster. As the heat needed for decomposition of the material is also partially delivered during torrefaction stage, this could also be considered a way to save some amounts of precious electricity. 
Introduction of the torgas into the gasifier can be seen as a way of simplification of the installation due to eliminating the need to build a separate torgas burner. Freeboard of the plasma gasifier seems to be a perfect place for a subsequent reforming of torgas, as refractory acts as a good insulation and temperatures in the chamber are generally high, due to the use of plasma. However, additional volume of the gases in the freeboard might require that section to be somewhat oversized, in comparison to regular plasma gasifiers. Further tests with plasma gasifier are needed to confirm merits of integration of the torrefaction unit into the installation.

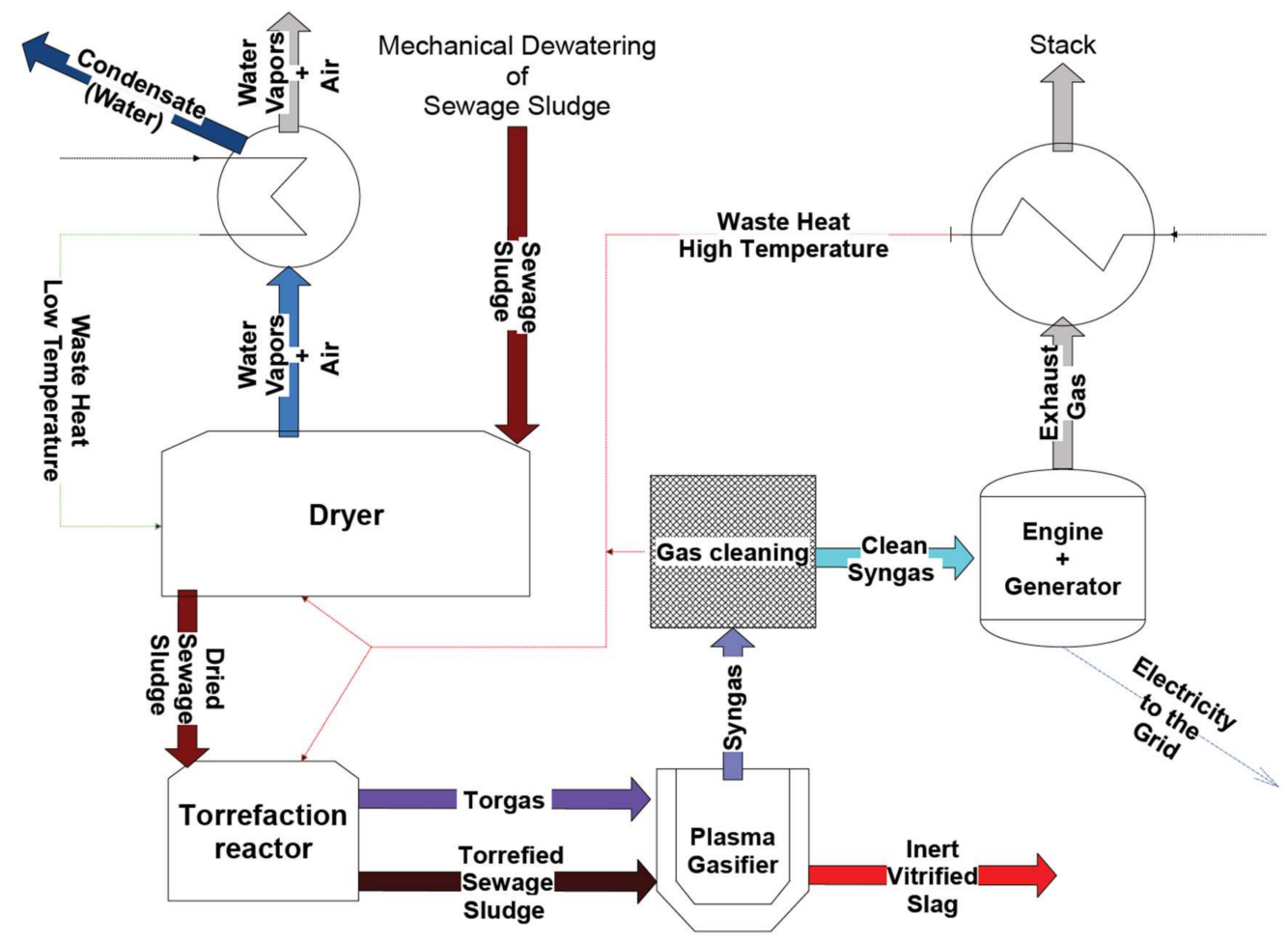

Figure 5. Diagram of the novel installation for utilization of sewage sludge.

\section{Conclusions}

A suite of experiments performed within the scope of this work, indicated the feasibility of the concept of proposed installation for sustainable, thermal utilization of sewage sludge. If self-sustainability of the installation is taken into consideration, minimalization of the footprint and the energy consumption is not the only factor that determines the choice of drying technology. Presence of relatively high amounts of low temperature heat, dictates the use of a staged, hybrid drying process or big unit, that would be able to effectively use a drying agent at relatively low temperatures that could be achieved by condensing heat exchangers. In that context maximalization of the dewatering capacity, during mechanical dewatering stage, seems to be crucial for achieving a favorable heat balance of the installation. Moreover, special attention should be directed at hybrid drying methods (convective-conductive) as they enable the possibility to recover heat from the vapors at the outlet of the dryer, thus potentially improving the efficiency of the process.

The use of torrefaction as an intermediate stage, between drying and plasma gasification, seems to be beneficial overall. Torrefaction of the sewage sludge leads to its further carbonization and increase of the ash content, which is not problematic in the proposed installation, as released volatiles are introduced into the gasifier anyway and inorganic fraction of the material will become a subject of a subsequent vitrification. Ability to remove a part of the nitrogen from the sewage sludge, during torrefaction, seems to be beneficial, due to a reducing conditions in the subsequent stage (gasification) 
which might lead to overall decrease of the $\mathrm{NO}_{\mathrm{x}}$ emissions during subsequent combustion of the gas in the engine.

Further tests with plasma gasifier are required to fully confirm all the benefits of combining torrefaction and plasma gasification into the complete system of thermal utilization of sewage sludge, in the way that has been proposed in this study. The proposed installation corresponds well with the goal 12 of the Sustainable Development Goals agenda, set by the United Nations for the years 2015-2030, in terms of reduction of waste, recovery of water, as well as energy savings.

Acknowledgments: This work was supported by Regional Operational Program for the Opole Voivodship 2014-2020, Priority Axis 01 Innovation in the Economy, Measure 1.1 Innovation in the Economy. Key Project No. RPOP.01.01.00-16-44/2016.

Author Contributions: Wilhelm Jan Tic, Joanna Guziałowska-Tic, Halina Pawlak-Kruczek, Eugeniusz Woźnikowski and Adam Zadorożny conceived the concept of the installation as well as the concept of the paper. They analyzed the results obtained from the measurements and took part in writing the paper. Moreover, Halina Pawlak-Kruczek played an advisory role, checked and approved the study at its present form. Łukasz Niedźwiecki wrote significant part of the paper and took part in the design of modernization of the torrefaction rig. Mateusz Wnukowski designed the sampling system for the measurement of the concentration of tarry compounds in torgas and performer GC-MS analysis. Krystian Krochmalny designed the sampling system for measuring of gaseous compounds of torgas. Michał Czerep and Michał Ostrycharczyk took part in the design of the measurement system for the drying tests. Marcin Baranowski took part in the drying tests and drawn the diagram of the dryer and the measurement system for drying tests. Jacek Zgóra analyzed the results obtained from the measurements of the flow rates and performed calculations of the heat delivered to the dryer. Mateusz Kowal performed proximate and ultimate analyses.

Conflicts of Interest: The authors declare no conflict of interest.

\section{References and Note}

1. Kacprzak, M.; Neczaj, E.; Fijałkowski, K.; Grobelak, A.; Grosser, A.; Worwag, M.; Rorat, A.; Brattebo, H.; Almås, Å.; Singh, B.R. Sewage sludge disposal strategies for sustainable development. Environ. Res. 2017, 156, 39-46. [CrossRef] [PubMed]

2. Lee, L.H.; Wu, T.Y.; Shak, K.P.Y.; Lim, S.L.; Ng, K.Y.; Nguyen, M.N.; Teoh, W.H. Sustainable approach to biotransform industrial sludge into organic fertilizer via vermicomposting: A mini-review. J. Chem. Technol. Biotechnol. 2018, 93, 925-935. [CrossRef]

3. Cieślik, B.M.; Namieśnik, J.; Konieczka, P. Review of sewage sludge management: Standards, regulations and analytical methods. J. Clean. Prod. 2015, 90, 1-15. [CrossRef]

4. Andersen, A. Disposal and Recycling Routes for Sewage Sludge Part 4: Economic Report; Office for Official Publications of the European Communities: Luxembourg, 2002.

5. Andersen, A. Disposal and Recycling Routes for Sewage Sludge: Part 1-Sludge use acceptance; Office for Official Publications of the European Communities: Luxembourg, 2001.

6. Werle, S.; Wilk, R.K. A review of methods for the thermal utilization of sewage sludge: The Polish perspective. Renew. Energy 2010, 35, 1914-1919. [CrossRef]

7. Chen, G.; Yue, P.L.; Mujumdar, A.S. Sludge dewatering and drying. Dry. Technol. 2002, 20, 883-916. [CrossRef]

8. Tunçal, T.; Uslu, O. A Review of Dehydration of Various Industrial Sludges. Dry. Technol. 2014, 32, 1642-1654. [CrossRef]

9. Peeters, B. Mechanical dewatering and thermal drying of sludge in a single apparatus. Dry. Technol. 2010, 28, 454-459. [CrossRef]

10. Bennamoun, L.; Arlabosse, P.; Léonard, A. Review on fundamental aspect of application of drying process to wastewater sludge. Renew. Sustain. Energy Rev. 2013, 28, 29-43. [CrossRef]

11. Ferrasse, J.H.; Arlabosse, P.; Lecomte, D. Heat, momentum, and mass transfer measurements in indirect agitated sludge dryer. Dry. Technol. 2002, 20, 749-769. [CrossRef]

12. Arlabosse, P.; Chavez, S.; Lecomte, D. Method for thermal design of paddle dryers: Application to municipal sewage sludge. Dry. Technol. 2004, 22, 2375-2393. [CrossRef]

13. Peeters, B.; Vernimmen, L. Challenges of Handling Filamentous and Viscouis Wastewater Sludge. Chem. Eng. 2016. 
14. Peeters, B.; Dewil, R.; Van Impe, J.F.; Vernimmen, L.; Smets, I.Y. Using a Shear Test-Based Lab Protocol to Map the Sticky Phase of Activated Sludge. Environ. Eng. Sci. 2011, 28, 81-85. [CrossRef]

15. Peeters, B.; Dewil, R.; Vernimmen, L.; Van den Bogaert, B.; Smets, I.Y. Addition of polyaluminiumchloride $(\mathrm{PACl})$ to waste activated sludge to mitigate the negative effects of its sticky phase in dewatering-drying operations. Water Res. 2013, 47, 3600-3609. [CrossRef] [PubMed]

16. Deng, W.; Su, Y.; Yu, W. Theoretical Calculation of Heat Transfer Coefficient When Sludge Drying in a Nara-Type Paddle Dryer Using Different Heat Carriers. Procedia Environ. Sci. 2013, 18, 709-715. [CrossRef]

17. Moscicki, K.J.; Niedzwiecki, L.; Owczarek, P.; Wnukowski, M. Commoditization of biomass: Dry torrefaction and pelletization-a review. J. Power Technol. 2014, 94, 233-249.

18. Moscicki, K.J.; Niedzwiecki, L.; Owczarek, P.; Wnukowski, M. Commoditization of wet and high ash biomass: Wet torrefaction-A review. J. Power Technol. 2017, 97, 354-369.

19. Wnukowski, M.; Owczarek, P.; Niedźwiecki, Ł. Wet Torrefaction of Miscanthus-Characterization of Hydrochars in View of Handling, Storage and Combustion Properties. J. Ecol. Eng. 2015, 16, 161-167. [CrossRef]

20. Magdziarz, A.; Wilk, M.; Kosturkiewicz, B. Investigation of sewage sludge preparation for combustion process. Chem. Process Eng.-Inz. Chem. Proces. 2011, 32, 299-309. [CrossRef]

21. Magdziarz, A.; Werle, S. Analysis of the combustion and pyrolysis of dried sewage sludge by TGA and MS. Waste Manag. 2014, 34, 174-179. [CrossRef] [PubMed]

22. Huang, M.; Chang, C.C.; Yuan, M.H.; Chang, C.Y.; Wu, C.H.; Shie, J.L.; Chen, Y.H.; Chen, Y.H.; Ho, C.; Chang, W.R.; et al. Production of torrefied solid bio-fuel from pulp industry waste. Energies 2017, 10, 910. [CrossRef]

23. Huang, Y.-F.; Sung, H.-T.; Chiueh, P.-T.; Lo, S.-L. Microwave torrefaction of sewage sludge and leucaena. J. Taiwan Inst. Chem. Eng. 2017, 70, 236-243. [CrossRef]

24. Huang, Y.-F.; Sung, H.-T.; Chiueh, P.-T.; Lo, S.-L. Co-torrefaction of sewage sludge and leucaena by using microwave heating. Energy 2016, 116, 1-7. [CrossRef]

25. Huang, Y.W.; Chen, M.Q.; Luo, H.F. Nonisothermal torrefaction kinetics of sewage sludge using the simplified distributed activation energy model. Chem. Eng. J. 2016, 298, 154-161. [CrossRef]

26. Do, T.X.; Lim, Y.; Cho, H.; Shim, J.; Yoo, J.; Rho, K.; Choi, S.-G.; Park, B.-Y. Process modeling and energy consumption of fry-drying and torrefaction of organic solid waste. Dry. Technol. 2017, 35, 754-765. [CrossRef]

27. Pulka, J.; Wiśniewski, D.; Gołaszewski, J.; Białowiec, A. Is the biochar produced from sewage sludge a good quality solid fuel? Arch. Environ. Prot. 2016, 42, 125-134. [CrossRef]

28. Poudel, J.; Ohm, T.I.; Lee, S.H.; Oh, S.C. A study on torrefaction of sewage sludge to enhance solid fuel qualities. Waste Manag. 2015, 40, 112-118. [CrossRef] [PubMed]

29. Poudel, J.; Karki, S.; Gu, J.H.; Lim, Y.; Oh, S.C. Effect of Co-Torrefaction on the Properties of Sewage Sludge and Waste Wood to Enhance Solid Fuel Qualities. J. Residuals Sci. Technol. 2017, 14, 23-36. [CrossRef]

30. Atienza-Martínez, M.; Fonts, I.; ábrego, J.; Ceamanos, J.; Gea, G. Sewage sludge torrefaction in a fluidized bed reactor. Chem. Eng. J. 2013, 222, 534-545. [CrossRef]

31. Atienza-Martínez, M.; Mastral, J.F.; Ábrego, J.; Ceamanos, J.; Gea, G. Sewage sludge torrefaction in an auger reactor. Energy Fuels 2015, 29, 160-170. [CrossRef]

32. He, C.; Giannis, A.; Wang, J.Y. Conversion of sewage sludge to clean solid fuel using hydrothermal carbonization: Hydrochar fuel characteristics and combustion behavior. Appl. Energy 2013, 111, 257-266. [CrossRef]

33. Danso-Boateng, E.; Shama, G.; Wheatley, A.D.; Martin, S.J.; Holdich, R.G. Hydrothermal carbonisation of sewage sludge: Effect of process conditions on product characteristics and methane production. Bioresour. Technol. 2015, 177, 318-327. [CrossRef] [PubMed]

34. Danso-Boateng, E.; Holdich, R.G.; Martin, S.J.; Shama, G.; Wheatley, A.D. Process energetics for the hydrothermal carbonisation of human faecal wastes. Energy Convers. Manag. 2015, 105, 1115-1124. [CrossRef]

35. Oh, S.Y.; Yoon, Y.M. Energy recovery efficiency of poultry slaughterhouse sludge cake by hydrothermal carbonization. Energies 2017, 10, 1876. [CrossRef]

36. Syed-Hassan, S.S.A.; Wang, Y.; Hu, S.; Su, S.; Xiang, J. Thermochemical processing of sewage sludge to energy and fuel: Fundamentals, challenges and considerations. Renew. Sustain. Energy Rev. 2017, 80, 888-913. [CrossRef] 
37. Tomasi Morgano, M.; Leibold, H.; Richter, F.; Stapf, D.; Seifert, H. Screw pyrolysis technology for sewage sludge treatment. Waste Manag. 2018, 73, 487-495. [CrossRef] [PubMed]

38. Fonts, I.; Gea, G.; Azuara, M.; Ábrego, J.; Arauzo, J. Sewage sludge pyrolysis for liquid production: A review. Renew. Sustain. Energy Rev. 2012, 16, 2781-2805. [CrossRef]

39. Atienza-Martínez, M.; Ábrego, J.; Mastral, J.F.; Ceamanos, J.; Gea, G. Energy and exergy analyses of sewage sludge thermochemical treatment. Energy 2018, 144, 723-735. [CrossRef]

40. Manara, P.; Zabaniotou, A. Towards sewage sludge based biofuels via thermochemical conversion-A review. Renew. Sustain. Energy Rev. 2012, 16, 2566-2582. [CrossRef]

41. Pečkytè, J.; Baltrènaitè, E. Assessment of heavy metals leaching from (bio) char obtained from industrial sewage sludge. Environ. Prot. Eng. 2015, 7, 399-406. [CrossRef]

42. Council of the European Union 2003/33/EC - Council Decision establishing criteria and procedures for the acceptance of waste at landfills pursuant to Article 16 of and Annex II to Directive 1999/31/EC. Off. J. Eur. Communities 2003, L 11/27, 27-49.

43. Wang, N.Y.; Shih, C.H.; Chiueh, P.T.; Huang, Y.F. Environmental effects of sewage sludge carbonization and other treatment alternatives. Energies 2013, 6, 871-883. [CrossRef]

44. Werle, S.; Dudziak, M. Analysis of organic and inorganic contaminants in dried sewage sludge and by-products of dried sewage sludge gasification. Energies 2014, 7, 462-476. [CrossRef]

45. Werle, S. Gasification of a Dried Sewage Sludge in a Laboratory Scale Fixed Bed Reactor. Phys. Procedia 2015, 66, 253-256. [CrossRef]

46. Reed, T.B.; Gaur, S. A Survey of Biomass Gasification 2001: Gasifier Projects and Manufacturers Around the World; The Biomass Energy Foundation: Golden, CO, USA, 2001.

47. Pigneri, A.; Asbjerg, M.; Collin, C.; Dicks, A.; Sproule, G. Gasification Technologies Review; The council of the city of Sydney: Sydney, Australia, 2014.

48. Maczka, T.; Sliwka, E.; Wnukowski, M.; Niedzwiecki, L. Pilot installation for thermal plasma treatment of plastic wastes. In Finnish-Swedish Flame Days 2013; IFRF International Flame Research Foundation: Sheffield, UK, 2013.

49. Willis, K.P.; Osada, S.; Willerton, K.L. Plasma Gasification: Lessons Learned at Eco-Valley WTE Facility. In Proceedings of the 18th Annual North American Waste-to-Energy Conference, Orlando, FL, USA, 11-13 May 2010; pp. 133-140.

50. Mountouris, A.; Voutsas, E.; Tassios, D. Plasma gasification of sewage sludge: Process development and energy optimization. Energy Convers. Manag. 2008, 49, 2264-2271. [CrossRef]

51. Fabry, F.; Rehmet, C.; Rohani, V.; Fulcheri, L. Waste gasification by thermal plasma: A review. Waste Biomass Valoriz. 2013, 4, 421-439. [CrossRef]

52. Kordylewski, W.; Michalski, J.; Ociepa, M.; Wnukowski, M. A microwave plasma potential in producer gas cleaning-preliminary results with a gas derrived from a sewage sludge. In VI Konferencja Naukowo-Techniczna Energetyka Gazowa 2016; Silesian University of Technology: Gliwice, Poland, 2016.

53. Striūgas, N.; Valinčius, V.; Pedišius, N.; Poškas, R.; Zakarauskas, K. Investigation of sewage sludge treatment using air plasma assisted gasification. Waste Manag. 2017. [CrossRef] [PubMed]

54. CEN (European Comitte for Standardisation) EN 13284-1:2001 Stationary source emissions-Determination of low range mass concentration of dust-Part 1: Manual gravimetric method 2001.

55. Peeters, B.; Dewil, R.; Smets, I. Challenges of drying sticky wastewater sludge. Chem. Eng. (United States) 2014, 121, 51-54.

56. Pawlak-Kruczek, H.; Krochmalny, K.K.; Niedźwiecki, Ł.; Mościcki, K.J. Slow pyrolysis of the sewage sludge with additives: Calcium oxide and lignite. In The Clearwater Clean Coal Conference: Proceedings of the 42nd International Technical Conference on Clean Energy; Sakkestad, B.A., Ed.; Coal Technologies Associates: Clearwater, FL, USA, 2017.

57. Pawlak-Kruczek, H.; Zgóra, J.M.; Krochmalny, K.K. Characterization of torrefied biomass depends on process condition. In Proceedings of the 40th International Technical Conference on Clean Coal \& Fuel Systems, Clearwater, FL, USA, 31 May-4 June 2015.

(C) 2018 by the authors. Licensee MDPI, Basel, Switzerland. This article is an open access article distributed under the terms and conditions of the Creative Commons Attribution (CC BY) license (http:/ / creativecommons.org/licenses/by/4.0/). 